\title{
Esadu Ćimiću u čast: zbornik radova povodom 80. godina života
}

DOI: 10.11567/met.29.1.5

\section{Aleksandar Vukić}

Institut za migracije i narodnosti, Zagreb

U svijetu, a i kod nas, uobičajeno je izdavanje zbornika u čast eminentnim znanstvenicima. Ti su zbornici, koliko nam je poznato, koncipirani na dva načina: 1) značajni autori govore o određenim aspektima djela još značajnijeg autora (npr. zbornik iz 1977. u čast Talcottu Parsonsu, ur. Jan J. Loubser) ili 2) zbornici u kojima se razrađuje neka teorijska koncepcija autora u čiju je čast zbornik priređen (npr. zbornik iz 1975. u čast Robertu K. Mertonu The Idea of Social Structure, ur. Lewis A. Coser). To je tako na Zapadu, gdje relativno stabilni društveni uvjeti stvaraju preduvjete za predvidljive putanje karijera znanstvenika. Eric Hobsbawm primjerice prekida svoju sjajnu autobiografiju Zanimljiva vremena u šezdesetim godinama dvadesetog stoljeća, konstatirajući da se nakon što je postao redoviti profesor (zbog marksističkog opredjeljenja njegova je karijera na liberalnom Zapadu bila usporena) u njegovu osobnom životu nije događalo ništa zanimljivo ni neuobičajeno. Predavanja, knjige, skupovi, nastupi na televiziji, predavanja i opet knjige. Ništa važno da bi ušlo u autobiografiju.

Znanstvenici na našim prostorima, a posebno neovisni intelektualci poput profesora Esada Ćimića, nisu imali takav privilegij »dosadnoga «kabinetskog života. Zbog toga držimo da je uređivačka koncepcija urednika zbornika Esadu Ćimiću u čast: zbornik radova povodom 80. godina života (Zadar, Sveučilište u Zadru, 2011, 238 str.) dr. sc. Nikole Skledara pun pogodak. U Zborniku su prezentirani radovi koji govore o životu i radu prof. dr. sc. Ćimića i društvenom kontekstu u kojem je njegovo djelo nastajalo, a bez čijega poznavanja ne bi bila moguća evaluacija tog značajnog opusa. Tu su i prilozi koji govore o osebujnoj ličnosti profesora Ćimića, o njegovoj metodi i teorijskom pristupu te radovi koji pokušavaju odrediti njegov znanstveni doprinos u kontekstu južnoslavenske sociologije religije. Naposljetku, ali ne i najmanje važno, urednik je »dopustio« da i glavni junak Zbornika prof. Ćimić progovori glasom iz davnine, koji dolazi iz danas već zaboravljenoga društvenog poretka što se nazivao socijalističkim samoupravljanjem. Odjednom, kao čarolijom, ideje o religiji, samoupravljanju, humanizmu i 
istinskom zajedništvu kao preduvjetu slobode svakog pojedinca izranjaju pred nama ne kao arheološke okamine misli i ideja, nego kao, danas više nego ikada, prisjećanje na »polet naše mladosti« (Zinovjev), kada se vjerovalo da je »carstvo slobode« odmah iza ugla. $S$ druge strane, taj stari intervju, objavljen u časopisu Pitanja br. 4/5 u Zagrebu 1980., pokazuje što se u ono vrijeme zahtijevalo od čovjeka koji je bio javna ličnost i predstavnik humanističke inteligencije. Zahtijevala se, a to je vidljivo u svakom odgovoru profesora Ćimića, obrazovanost - u onom smislu koji tom pojmu daje sjajni austrijski filozof Konrad Liesmann - obrazovanost kao poznavanje kanona znanja, što je neophodan uvjet da bi se netko mogao nazivati intelektualcem. U to je doba taj kanon barem u Europi određivao marksizam, kao legitimni nasljednik i čuvar ideja prosvjetiteljstva. To je bilo tako bio netko marksist ili ne. Konačno, i djela Comtea, Webera i Durkheima, koja su politički konzervativna u odnosu na marksizam, ne mogu se dobro razumjeti ako se uvijek iznova ne upozori na njihov odnos prema Marxu i marksizmu. Ideja da se uvrsti stari intervju (vjerojatno s dopuštenjem profesora Ćimića) govori da se promjenom političkoga konteksta istinski marksistički humanisti nisu odrekli svojih ideja. Dogmatski marksisti lako su postajali nacionalisti, liberali, konzervativci ili što već, a pomodni, najčešće francuski, marksisti, staljinisti i maoisti postali su mrzitelji ideja prosvjetiteljstva i socijalizma.

Zbornik se sastoji od sedamnaest priloga, od kojih su neki pretiskani iz starijih časopisa. Kako bi prikaz svakoga priloga uzeo mnogo prostora, a neke ocjene i stavovi u njima se i poklapaju, opredijelili smo se za sintetički pristup te priloge Zbornika podijelili na tri skupine. U prvoj su radovi koji govore o karijeri prof. Ćimića kao sociologa i filozofa religije u kontekstu društvenih sistema u kojima je djelovao (Nikola Skledar, »Prof. emeritus dr. sc. Esad Ćimić, život i djelo«, Željka Tonković, »Sociologija Esada Ćimića - dokument jednog vremena«, i Dragoljub B. Đorđević, »Esad Ćimić /1931.- / sociolog religije izvorne misli«). Drugu grupu čine radovi o metodi i teorijskom pristupu prof. Ćimića (Mislav Kukoč, »Sociološka imaginacija Esada Ćimića«, i Mladen Labus, »Sociolog religije i humanist Esad Ćimić«). U trećoj su radovi koji govore o ličnosti i utjecaju ideja profesora Ćimića (Nikola Dugandžija, »Vrli duh znanosti /uz čitanje djela Esada Ćimića. Prisjećanja/«, Ivan Markešić, »S Ćimićem od Hercegovine preko Bosne do Hrvatske i natrag «, i Božo Rudež, »Esad Ćimić: erazmovski intelektualac i čovjek na dobitku«).

Skledar i Đorđević u svojim radovima daju podrobne i informativne preglede života i karijere profesora Ćimića. Tako saznajemo da je rođen 1931. u Mostaru, u kojem je završio srednju školu. Diplomirao je filozo- 
fiju u Sarajevu, a doktorirao 1964. s tezom Socijalističko društvo i religija (mentor Ante Fiamengo, predsjednik povjerenstva Vanja Sutlić - legendarni zagrebački filozof o kojemu kruže anegdote, istinite ili ne, da je i na samoj obrani znao srušiti neke kandidate). Izabran je za docenta na Filozofskom fakultetu u Sarajevu, ali je nekoliko godina poslije zbog knjige Čovjek na raskršću i svojih stavova o muslimanskoj naciji izbačen s Fakulteta zbog tzv. »moralno političke nepodobnosti«. Od 1976. radi u Zadru, gdje 1978. osniva i utemeljuje Odsjek za sociologiju. Od 1982. do izbijanja posljednjih ratova predaje sociologiju religije i morala u Beogradu. Od 1992. radi u Institutu »Ivo Pilar«, gdje je od 1993. do 1996. bio ravnateljem. Godine 1996. vraća se na fakultet u Zadru i tamo radi do umirovljenja. U svojoj karijeri vodio je postdiplomski studiji iz Sociologije religije u Zagrebu, predavao na Katoličkome bogoslovnom fakultetu u Zagrebu, Pravnom fakultetu u Splitu te na dva fakulteta u Ljubljani. Sada je profesor emeritus Sveučilišta u Splitu i Sveučilišta u Zadru.

Skledar i Đorđević u svojim prilozima ističu da je prof. Ćimić autor više od sedamdeset znanstvenih radova, više od sto stručnih radova i deset knjiga. Dragoljub B. Đorđević, koji se bavi poviješću sociologije religije, u svojem članku tvrdi da sociolozi na pitanje koja im je najdraža Ćimićeva knjiga daju različite odgovore. Za njega samoga, kao i za autora ovoga prikaza, to je Drama ateizacije. Iako ta rana knjiga svakako nije posljednja riječ profesora Ćimića o religijskom fenomenu, ona je vjerojatno najviše utjecala na sociologe s ovih prostora jer je doživjela pet izdanja, bila objavljivana u Sarajevu, Beogradu i Zagrebu te prevedena na slovenski objavljena u Ljubljani.

Željka Tonković u svojem prilogu daje sažet ali produbljen prikaz najznačajnijih djela profesora Ćimića u kontekstu vremena njihova nastanka. Djela izlaže kronološkim redom i upozorava na najznačajnije Ćimićeve ideje koje i danas snažno utječu na sociologe religije. Tako autorica svoj prilog počinje prikazom Ćimićeve prve knjige Socijalističko društvo i religija i naglašava kako je ona nastala 1963. kao rezultat prvoga empirijskog istraživanja sociologije religije na tlu bivše Jugoslavije. Cilj istraživanja bio je istražiti utjecaj socijalističkog samoupravljanja na procese ateizacije. Već u toj knjizi Ćimić dolazi do jedne od svojih ključnih ideja - razlikovanja religije i religioznosti. Za njega je religija u tradicionalističkom smislu uvijek bila oblik otuđenja čovjeka, dok istinska religioznost, koja izvire iz uvjeta same »ljudske situacije« $i$ čovjekove psihološke strukture, nikada ne iščezava, nego se neprestano mijenja. Te početne i, pokazat će se, plodonosne ideje o odnosu pojedinca, društva, religije i religioznosti Ćimić produbljuje u knjigama Drama ateizacije, Ateizam kao povijesni humanizam i Dogma i sloboda. U Drami 
ateizacije dublje je razradio svoj marksističko-humanistički pristup religijskom fenomenu u originalnoj koncepciji koja razlikuje tri razine religije i religioznosti: religiju per se, religiju kao povijesno-socijalnu činjenicu i religiju kao (onto)antropološko-psihološku strukturu. Prema mišljenju Siniše Zrinščaka, s kojim se autorica priloga slaže, upravo je konceptom religije per se (koja je, prema Ćimiću, »teorijska konstrukcija koja omogućuje tretiranje relativne autonomije religijskih odgovora na tzv. posljednja pitanja«) Ćimić otišao najdalje u reviziji marksističkog pristupa religiji, što je predstavljalo znatan teorijski iskorak. Ćimićeva djela Socijalističko društvo i religija i Čovjek na raskršću nisu samo reinterpretacija marksizma već i snažna kritika jugoslavenskog društva i devijacijâ samoupravnog socijalizma. Zasad posljednja Ćimićeva knjiga Iskušenja zajedništva još jednom svjedoči o autorovoj sociološkoj imaginaciji, prije svega u originalnoj interpretaciji odnosa nacije i religije. Taj odnos Ćimić slikovito prikazuje kao odnos »univerzalne zajedni-

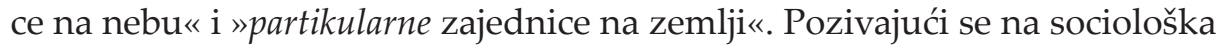
istraživanja, zaključuje da je religija trajna i sveprisutna socijalna činjenica, a nacija i nacionalizam možda su tek faza u razvoju modernog društva.

Metodologijom istraživanja religije i teorijskim pristupom profesora Ćimića bave se, prije svega, radovi Mislava Kukoča i Mladena Labusa. Po Mislavu Kukoču, Ćimićev teorijsko-metodološki pristup nadovezuje se na shvaćanje C. W. Millsa prema kojem se pristup sociologije svojemu predmetu nalazi na sredini između apstraktne »super teorije « Talcotta Parsonsa (krajem 20. stoljeća tu je poziciju reafirmirao Niklas Luhmann) i ekstremnog empirizma utjelovljenog $\mathrm{u}$ anketama, koji je bio popularan u SAD-u pedesetih godina 20. stoljeća, a u Hrvatskoj početkom 21. stoljeća. Kombiniranjem Marxova povijesnog pristupa i weberovske metode razumijevanja Mills je razvio pojam sociološke imaginacije, koja je u biti interpretativna metoda kojom se osobne biografije, ideje i vjerovanja uklapaju u šire povijesne tokove. Sociološka imaginacija profesora Ćimića po Kukočevu je mišljenju na tragu tih Millsovih ideja.

Mladen Labus pokazuje da je osnovni medij Ćimićeva izražavanja ideja znanstveni esej. Znanstveni esej osnovna je forma Ćimićeve refleksivne, odnosno interpretativne sociologije religije. Esej je, smatra Labus, logični i jedini mogući oblik (forma) kroz koji se mogao ostvariti Ćimićev višedimenzionalni pristup religiji i društvu. $U$ formi eseja isprepleću se znanstveni, filozofski i književni diskurs kao izrazi Ćimićeva višedimenzionalnoga metodološkog pristupa i teorijskog shvaćanja da sociologija mora biti refleksivna, a ne pozitivistička znanost. Sociologija se, prema Ćimiću, treba baviti otkrivanjem i razumijevanjem mreža značenja koje su ispleli ljudi u 
svojoj interakciji i refleksiji. Zbog takva pristupa, prema Labusovu mišljenju, Ćimić je, zbog toga što je, prije svega, filozof koji sagledava društvo i religiju s različitih motrišta, i mogao postati sociolog od velike važnosti.

Kao što je rečeno u uvodu ovoga prikaza, nekoliko je važnih radova Zbornika posvećeno Ćimićevoj osebujnoj ličnosti i vrednovanju njegovih glavnih ideja. Čitajući te priloge, postavilo nam se pitanje je li se bilo tko od njihovih autora približio »istini « o ličnosti i idejama profesora Ćimića. Ili se istina o Ćimićevoj osobi možda nalazi u sintezi različitih motrišta autora tih priloga? Dobar odgovor na filozofsko pitanje što je znanstvena istina dao je u svojoj knjizi Znanost društva Niklas Luhmann. Njegove nas ideje mogu približiti pitanju o biti nečije ličnosti i njezinim idejama. Luhmann smatra da nam je svijet dostupan preko generaliziranih medija prijenosa i razmjene informacija. U procesu promatranja (shvaćenog kao postupak konstruiranja realnosti), a u našem slučaju riječ je o ljudima koji promatraju život i djelo profesora Ćimića, uspostavlja se određena hijerarhija u odnosu na predmet promatranja. Tako je profesor Ćimić promatrač prvog stupnja (onaj koji neposredno promatra fenomene koje istražuje), profesori Rudež, Markešić i Dugandžija promatrači su drugog stupnja, te ne mogu drugo nego promatrati kako prof. Ćimić promatra svijet, kakva je on osoba, koje su njegove glavne ideje te kako su one povezane s njegovom ličnošću. Na kraju se javlja i autor ovog prikaza kao promatrač trećeg stupnja koji govori o tome kako promatrači drugog stupnja govore o promatraču prvog stupnja - profesoru Ćimiću. Promatrač trećeg stupnja mogao se pojaviti i kao promatrač drugog stupnja jer je bio njegov student te čitao neke njegove knjige i radove, ali tada bi on bio autor priloga u Zborniku, a ne samo prikazivač Zbornika. No ta pozicija promatrača trećeg stupnja omogućuje vrednovanje stavova promatrača drugog stupnja kroz pitanje kako oni nešto vide i zašto to vide upravo tako. Tako Markešić naglašava važnost zavičaja i ljudi, ali i društveno-povijesnih uvjeta za razumijevanje Ćimićeve ličnosti i djela. Naime profesor Ćimić rođen je i školovao se u Mostaru, gradu u kojem su možda najčvršće isprepleteni islam, katoličanstvo i pravoslavlje. Kada se tomu pridoda i ateistička komunistička ideologija u čijem se ozračju nakon Drugoga svjetskog rata Ćimić intelektualno formirao, postaje, po Markešiću, jasno zašto je glavno područje njegova interesa postala sociologija religije. Ćimić je od početka osjećao da je religija kao fenomen »dugog trajanja « ključ za razumijevanje jugoslavenskog društva - njegove prošlosti, sadašnjosti, a, pokazat će se, i budućnosti. Ćimić je od svojega prvog istraživanja provedenog u istočnoj i zapadnoj Hercegovini bio posebno zaokupljen odnosom nacionalnoga i religijskoga u Bosni i Hercegovini, procesima ateizacije, a poslije 
i ponovne teizacije društva te ulogom vjerskih elita i zajednica u stvaranju nacija (napose muslimanske, poslije bošnjačke). I kada je morao napustiti Bosnu i Hercegovinu jer je bio proskribiran kao neprijatelj te zemlje i muslimana, a samim tim i komunističkog poretka, Ćimiću je Bosna i Hercegovina ostala svojevrsni sociološki laboratorij u kojem se najbolje mogu sagledati procesi koji su relevantni ne samo na regionalnoj nego i na globalnoj razini - procesi nacionaliziranja i politiziranja religije i religijskih zajednica, ali i religizacija političkoga, uloga religijskih pokreta u sakralizaciji ratnih zločina te nastanak konzervativnih i fundamentalističkih religijskih svjetonazora. Markešić je veoma uspješno pokazao da se univerzalna vrijednost Ćimićeva sociološkog djela utemeljuje na dubokom i sveobuhvatnom promatranju fenomena na lokalnoj razini.

Božo Rudež u svojem radu Ćimića promatra kao erazmovskog intelektualca. Pojam »erazmovskog intelektualca« preuzima od Ralpha Dahrendorfa, koji ga je osmislio evocirajući velikoga renesansnoga humanista. Erazmovski intelektualci bili bi po Dahrendorfu samo oni koji svoje znanje i javni utjecaj nikada ne zlorabe kako bi služili nekom političkom ili nacionalnom interesu. U europskome dvadesetom stoljeću tom uskom krugu pripadaju Raymond Aron, Isaiah Berlin, Karl Poper, Norberto Bobbio, Jan Patočka, Theodor W. Adorno i Hannah Arendt. Proširujući Dahrendorfov model na prostor bivše Jugoslavije, Rudež drži da erazmovcima iz hrvatskoga kulturnoga kruga svakako pripadaju Miroslav Krleža, Ivo Politeo (čovjek koji je u političkim procesima bio branitelj Tita i Stepinca), iz srpskoga Rade Konstantinović i Danilo Kiš te iz bošnjačkoga Abdulah Šarčević, Abdulah Sidran i Esad Ćimić. No Ćimić je i u tom časnom društvu opet po nečemu izniman - kao i Erazmo i on je doživio da njegova knjiga bude spaljena na lomači. To se dogodilo u Tuzli, a skup spaljivača knjiga predvodio je jedan ideologijom zatrovan učitelj. On je od vlasti tražio i da se pisca »bezuvjetno i neodgodivo « objesi, i to što prije. Po mišljenju profesora Dugandžije, Ćimićevoj osobi i djelu najviše ćemo se približiti ako njegovu poziciju u svijetu i vremenu usporedimo sa Spinozinom. Obojica su »granični ljudi« u svakome mogućem smislu te riječi. Ta je pozicija dobra za mišljenje, ali teška za življenje. Po Dugandžiji, Ćimić je utjelovljenje Spinozina zavještaja da je za smislen život potrebno povezati spoznaju, razumijevanje, radost i ljubav. Dugandžija upozorava na činjenicu da prof. Ćimić rado citira Spinozu. Vjerojatno je i profesor Ćimić, kao i promatrač trećeg stupnja, autor ovog prikaza, ponekad pomislio da bi povijest socioloških ideja bila sasvim drugačija da su klasici sociologije uzeli u obzir sociološki potencijal Spinozinih filozofskih ideja, prije svega ono o determiniranosti čovjekove 
situacije fizičkim, biološkim, povijesnim i društvenim uvjetima. No klasici su izabrali Kanta, možda i zbog toga što su stvarali u doba europskog uzleta, optimizma te vjere u ljudsku slobodu izbora i neograničenu stvaralačku sposobnost čovjeka. Možda bi neki budući balkanski Weber mogao postaviti sociologiju na nove temelje počinjući od realističnije Spinozine vizije društvene stvarnosti i ljudske situacije.

Na kraju, kako bi promatrač trećeg stupnja vrednovao ovaj Zbornik i ono što nam promatrači drugog stupnja kazuju o životu i djelu profesora Ćimića? Zbornik je s različitih motrišta dao obilje podataka o životu i radu prof. Ćimića. Uspješno je povezao njegovu biografiju s društveno-povijesnim kontekstom u kojem je djelovao. Istaknuo je njegove glavne ideje i doprinos razvoju sociologije religije na južnoslavenskom prostoru. No s povlaštenog motrišta promatrača trećeg stupnja moguće je izvući još neke zaključke o životu i djelu profesora Ćimića. Za to je potrebno prizvati u pomoć Spinozu i teoretičare društvenih mreža. Spinoza bi vjerojatno rekao da je profesor Ćimić stvorio sebe i svoje djelo upravo zato i samo zato što je bio jedna od mogućnosti života u specifičnoj društvenoj, povijesnoj i materijalnoj situaciji Balkana u 20. stoljeću. Tu je, na području Jugoslavije, šezdesetih godina nastala društvena situacija u kojoj je bilo moguće kritizirati poredak i eventualno nastradati, ali kako nije postojalo jedno središte moći, nego ih je bilo barem šest, moglo se naći utočište na drugome mjestu u okviru istoga društvenog sistema. Profesor Ćimić je tako, po našemu mišljenju, osvojio slobodu prigrlivši ulogu Deleuzeova intelektualca »nomada«. To mu je omogućilo da ostane svoj (primjerice nikada se nije odrekao svojega hrvatskog identiteta, koji je prihvatio kod prvog popisa stanovništva) i da relativno nesmetano nastavi raditi mijenjajući samo svoje prebivalište.

Zbog toga njega treba vidjeti onako kako u jednoj intelektualnoj igri teoretičari mreža vide poznatoga glumca Kevina Bacona - kao središnju povezujuću osobu u povijesti američkog filma. Empirijsko je istraživanje pokazalo da je taj glumac osoba koja je glumila s najviše drugih glumaca, a ti su pak radili i s glumcima koji su stvarali i prije nego što je Bacon postao glumac. Kao što Bacon povezuje generacije američkih glumaca u prostoru i vremenu, tako i profesor Ćimić predstavlja kariku koja povezuje prostorvrijeme sociologije i sociologâ bivše Jugoslavije. 
